\title{
LUIGI PAPO (DE MONTONA): ANGAŽIRAN BORAC ZA TALIJANSKU ISTRU - OD RATA DO PSEUDOHISTORIJE
}

\author{
Vanni D’ALESSIO \\ Sveučilište u Rijeci \\ Filozofski fakultet, Sveučilišna avenija 4 \\ 51000 Rijeka \\ Università degli Studi di Napoli \\ Dipartimento di scienze sociali \\ Vico Monte della Pietà 1 \\ 80138 Napoli, Italija \\ vannidalessio@gmail.com
}

UDK 329.18Papo, L.(497.571)“1943/1945““

32-05Papo, L.

Prethodno priopćenje

\begin{abstract}
Luigi Papo bio je vođa motovunske fašističke skupine koja je sudjelovala u ratu s drugim dragovoljcima fašističkih milicija između 1943. i 1945. godine u Istri. Na kraju borbe uspio je, nakon kratka zatvora u Prestranku (Slovenija), pobjeći u Italiju kako bi izbjegao optužbe za ratne zločine koje je protiv njega pokrenula Jugoslavija. U sljedećim godinama Papo je nastavio svoj aktivizam: sada umjesto vojno djeluje politički, u udrugama istarskih ezula te u njihovim časopisima. Papo je bio plodan autor: napisao je brojne publikacije o staroj i novijoj povijesti Istre te o svojim iskustvima u ratu. Svojim stalnim aktivizmom sudjelovao je u izgradnji narativnoga diskursa o istarskom egzodusu i o fojbama te je imao snažan utjecaj u krugovima ezula i kasnije u različitim sektorima talijanske javnosti. Ovaj članak predstavlja neke trenutke Papova iskustva kao borca i pisca, a posebice raspravlja o njegovu dihotomnom pogledu na jezične i nacionalne odnose u Istri.
\end{abstract}

Ključne riječi: Luigi Papo, Drugi svjetski rat, Motovun, Istra, nacionalizam, fojbe, istarski egzodus

Keywords: $\quad$ Luigi Papo, Second World War, Motovun, Istria, nationalism, foibe, Istrian population transfer (exile)

Parole chiave: Luigi Papo, Seconda guerra mondiale, Montona, Istria, nazionalismo, foibe, esodo istriano

Luigi Papo, rođen u Gradu 23. lipnja 1922., bio je Istranin. Iz Grada je bila njegova majka, dok je otac bio rodom iz Motovuna u kojem je Papo živio od malih nogu. Za Motovun je ostao toliko vezan da je koristio njegovo uz vlastito ime: »Luigi Papo de Montona« 
(Luigi Papo Motovunac), kojim je potpisivao brojna djela o povijesti Istre, ali i o političkim traumama, kolektivnim i individualnim, talijanskih Istrana u dvadesetom stoljeću. ${ }^{1}$

Svoje je prve radove Luigi Papo potpisivao pseudonimom »Paolo De Franceschi«. Njime se koristio u razdoblju nakon Drugoga svjetskog rata kad se skrivao od optužbi Federativne Narodne Republike Jugoslavije (FNRJ) za ratne zločine počinjene izravno ili neizravno, kad je služio kao dragovoljac u redovima fašističkih jedinica za vrijeme njemačke okupacije istarskoga poluotoka i cijeloga sjeveroistočnog Jadrana. Prezime koje je u tom periodu Papo koristio kao pseudonim pripada njegovoj supruzi, kćeri motovunskoga liječnika Vittorija De Franceschija. Najvjerojatnije ga je odabrao zbog njegova talijanskoga podrijetla i stoljetne raširenosti u Istri. Papovo zagovaranje talijanskoga Motovuna i talijanske Istre obilježava njegove napore i politički rad tijekom cijeloga života, od mladosti kad se uključuje u rat kao dragovoljac te idućih desetljeća kada djeluje kao utjecajni pisac i aktivist u miljeu istarskih ezula i njihovih organizacija.

Motovun, kojem je Papo sredinom sedamdesetih posvetio dvije monografije (Montona i Montona tra realtà e sogno) ${ }^{2}$, predstavlja prostor snažne simboličnosti, sažimajući povijesne i nacionalne narative istarskih Talijana. Papo naglašava simboličko značenje Motovuna kao romanizirane, a zatim »venetizirane« stare gradine, nadovezujući se na taj način na temeljne diskurzivne elemente angažirane talijanske nacionalno orijentirane historiografije (i pseudohistoriografije). Na taj način grad Motovun postaje nositeljem važnoga metaforičkog značenja jer održava vojnu ulogu i simboliku s obzirom na to da se nalazi na granici sa starom austrijskom Istrom te tamo ima posebnu obrambenu vojnu ulogu u sklopu Mletačke Republike. Kao što to mogu vidjeti i turisti koji se letimično upoznaju s Istrom i njezinom poviješću, lavovi koji se još uvijek ističu na srednjovjekovnim zidinama prikazuju zatvorenu knjigu, a ne otvorenu kao na obali, u znak rata.

Papov poriv za pisanjem ne polazi od proučavanja ratnoga aspekta srednjovjekovnoga i ranomodernog Motovuna. On, kao i mnogi drugi poput njega, piše kako bi svjedočio i istakao talijanski karakter i obilježje ovoga gradića i čitave Istre, u kojima je stoljećima zapravo živjelo miješano stanovništvo. Međutim, Papova je tendencija da u potpunosti odvoji gradove od sela, shvaćajući gradove kao isključivo talijanske, poput mnogih intelektualaca među istarskim Talijanima koji nisu bili u stanju razumjeti porast hrvatske društvenosti u urbanim sredinama krajem 19. stoljeća. Neki su od njih istarsko društvo analizirali kroz prizmu vlastitoga viđenja tridesetih i četrdesetih godina 20. stoljeća kad je vidljivost elemenata hrvatske kulture, jezika i socijalizacije u gradovima bila zasjenjena politikom talijanizacije koju je provodio fašizam. Papo, koji nije bio povjesničar po struci, snažno apsolutizira, snažnije od talijanskih povjesničara i geografa kakvi su, primjerice, Ernesto Sestan i Carlo Schiffrer, granicu između gradova i sela gdje gradovi isključivo predstav-

Paolo RADIVO, »Luigi Papo de Montona«, Atti e Memorie della Società Istriana di Archeologia e Storia Patria, CX (LVIII), Trieste, 2010., str. 439-441.

2 Luigi PAPO, Montona, Liviana, Padova, 1974.; ISTI, Solfòra: Montona tra realtà e sogno, Famiglia montonese, Trieste, 1975. 
ljaju prostor talijanske kulture dok na selu žive, kako se to obično nazivalo u talijanskom liberalnom tisku 19. stoljeća u Istri, »seljaci« ili »Slaveni«. ${ }^{3}$

Istrovenetsko narječje dugo je prevladavalo u trgovačkim i kulturnim razmjenama u Istri, s uporištem u pisanoj kulturi razvijenoj na talijanskom jeziku unutar imućnoga društvenog sloja koji je obrazovanje stjecao u talijanskim jezičnim žarištima sjevernoga Jadrana, od Kopra do Trsta i Padove. Bilo je i ruralnih područja guste naseljenosti u kojima se govorilo pretežito istrovenetskim narječjem, kao što je slučaj s okolicom Buja i Vodnjana. Slavenski su se jezici i narječja, koji su općenito bili više rasprostranjeni među istarskim stanovništvom, pretežito govorili unutar obiteljskoga kruga i seljačkog stanovništva. Ipak, u drugoj polovici 19. stoljeća dolazi do društvenih i političkih promjena koje su omogućile porast broja stanovnika koji primarno koriste hrvatski jezik, pa i u urbanim prostorima unutrašnje i obalne Istre. ${ }^{4}$

Odnos i ravnotežu između dijalekata romanskih i slavenskih jezika nije jednostavno povijesno analizirati jer su žitelji koristili različite jezike i narječja ovisno o kontekstu višejezičnih područja u kojima etničke granice nisu uvijek definirane. Ovdje stanovnici, pa i danas, govore i koriste više jezika, ovisno o navici i potrebi. Unatoč svojoj isprepletenosti i kompleksnosti, prostori su »jezičnih granica« srednje Europe dugo bili proučavani iz vizure povijesne, etnografske i sociološke dihotomije s tipičnim nastojanjem da se sakrije ili ne prikaže prisutnost drugoga. ${ }^{5}$ Istra je jedna od tih europskih »jezičnih granica« lokalnih i nacionalnih jezika i identiteta, najviše slavenskih i romanskih, koji su se stoljećima isprepletali. Luigi Papo bio je tipičan predstavnik pristupa odnosno pogleda koji karakterizira izrazita dihotomija usmjerena na talijanski dio povijesti Istre. U njegovim naporima da potvrdi talijanski karakter Istre, nema pozornosti usmjerene na etničku kompleksnost i na prisutnost pripadnika jezične i kulturne nacionalnosti »drukčije« od njegove. S druge strane, ni neki ugledni povjesničari i angažirani intelektualci nisu bili skloni prepoznavanju

3 O Schiffreru i Sestanu vidi: Carlo SCHIFFRER, La questione etnica ai confini orientali d'Italia: antologia, ur. Fulvia VERANI, Italo Svevo, Trieste, 1990.; Ernesto SESTAN, Venezia Giulia: lineamenti di una storia etnica e culturale [1946], ur. Giulio CERVANI, Del Bianco, Udine, 1997.

O tome vidi: Vanni D’ALESSIO, »Riflessioni sul problema dell'identità etnica e nazionale nell'Istria tardoasburgica«, Ricerche Sociali, Centro di Ricerche Storiche di Rovigno, br. 8-9, Trieste-Rovigno, 1998./1999., str. 5-12; ISTI, Il Cuore Conteso. Il nazionalismo in una comunità multietnica. L'Istria Asburgica, Filema, Napoli, 2003.; Marina CATTARUZZA (ur.), Nazionalismi di frontiera: identità contrapposte sull'Adriatico nord-orientale, 1850-1950, Rubbettino, Soveria Mannelli, 2003.; Egidio IVETIC, »On Croatian Nation-Building in Istria (1900-1940)«, Jahrbücher für Geschichte und Kultur Südosteuropas, 8, München, 2006., str. 61-71; Nevio ŠETIĆ, Istra između tradicionalnog i modernog, ili, O procesu integracije suvremene hrvatske nacije u Istri, Naša sloga, Pazin, 1995.

5 Primjeri nove historiografije o srednjoj Europi koji proučavaju »jezične granice« (language frontiers) ili koji se protive nacionalnoj dihotomizaciji te su skloni isticati isprepletenost i mješovit karakter tih regija: Jeremy KING, Budweiseirs into Czechs: A Local History of Bohemian Politics, 1848-1948, Princeton University Press, Princeton, 2002.; Nancy M. WINGFIELD, Creating the Other. Ethnic Conflict and Nationalism in Habsburg Central Europe, Berghahn books, New York, 2003.; Pieter JUDSON, Guardians of the Nation: Activists on the Language Frontiers of Imperial Austria, Harvard Univ. Press, Cambridge, Mass., 2006.; Laurence COLE, Different Paths to the Nation: Regional and National Identities in Central Europe and Italy, 1830-70, Palgrave, Basingstoke, 2007.; James BJORK - Tomasz KAMUSELLA Tim WILSON - Anna NOVIKOC (ur.), Creating Nationality in Central Europe, 1880-1950: Modernity, Violence and (be) Longing in Upper Silesia, Routledge, New York, 2016. 
razine jezične i etničke isprepletenosti u Istri te su imali obrambeni stav prema vlastitoj kulturi. $^{6}$

U Motovunu, gdje je otac Guglielmo vodio lokalnu ljekarnu i predstavljao eminentnu ličnost fašističke stranke i pripadajućih udruga, Papo pohađa osnovnu školu u trenutku najveće ekspanzije i konsenzusa oko fašističke diktature u Italiji i Julijskoj krajini. Kao mladić, Luigi pohađa talijansku gimnaziju Gian Rinaldo Carli u Pazinu. Radi se o školi izrazitoga simboličkog značenja za povijest $\mathrm{i}$ identitet Talijana u Istri zbog napetih etničkih i nacionalnih odnosa koji su vladali između istarskih Talijana i Hrvata u samom gradu i okolici, inače isključivo naseljenim hrvatskim stanovništvom. ${ }^{7}$ Povijesno kulturno okruženje u kojem odrasta i obrazuje se, utječe stoga na njegov snažan patriotski, odnosno nacionalistički stav, koji karakterizira jaka simbolička i povijesna povezanost s tradicijom talijanskoga iredentizma. Odrastajući u obiteljskoj, školskoj i društvenoj sredini za koju je bila karakteristična idealna veza s iredentizmom i talijanskom nacijom, Papo se još kao maloljetni student na Sveučilištu u Trstu odlučuje unovačiti kao dragovoljac u Drugom svjetskom ratu.

Kao talijanski vojnik, Papo u sklopu Jedinice sveučilišnih dragovoljaca treće regimente grenadira Sardinije (Compagnia Volontari Universitari del $3^{\circ}$ Reggimento Granatieri di Sardegna) ratuje u sjevernoj Africi. No, zbog bolesti se uskoro vraća u Istru gdje će kasnije sudjelovati u obrani željezničkih konvoja na putu za Grčku. U trenutku kapitulacije Italije u rujnu 1943. nalazi se na dopustu u Motovunu gdje su ga partizani, ustali protiv talijanske vlasti, uhitili, a zatim i oslobodili.

Partizanski su ustanak, u kojem su sudjelovali i istarski Talijani, u središnjoj Istri predvodili tamošnji Hrvati. Trajao je otprilike mjesec dana, do dolaska njemačkih postrojba, te je ostao utisnut u kolektivno pamćenje čitave talijanske zajednice u Istri. S jedne strane fašistički napadi nakon Prvoga svjetskog rata i fašističko-nacistička represija nakon 1943., a s druge strane likvidacije brojnih civila koje su popratile partizanski ustanak 1943., osta-

6 Vidi, naprimjer: Tomaso LUCIANI, L'Istria: Schizzo Storico Etnografico, Tipografia Barbèra, Firenze, 1866.; Carlo De FRANCESCHI, L'Istria: Note Storiche, Coana, Parenzo, 1879.; Carlo COMBI, Istria: studi storici e politici, ur. Tomaso LUCIANI, Tip. Bernardoni, Milano, 1886.; Francesco SALATA, Il diritto d'Italia su Trieste e l'Istria: documenti, F.1li Bocca, Torino, 1915.; Dane GRUBER, Povijest Istre, Tiskara Ivan Lesnik, Zagreb, 1924. [repr. Katedra Čakavskoga sabora, Žminj, 2005.]; Bernardo BENUSSI, L'istria nei suoi due millenni di storia, Caprin, Trieste, 1924. [repr. Centro di ricerche storiche, Rovinj, 1997.]; Carlo De FRANCESCHI, Memorie Autobiografiche. Con prefazione, note e appendici a cura Del Figlio Camillo, ur. Camillo De FRANCESCHI, Lloyd triestino, Trieste, 1926.; Ernest RADETIĆ, Istra Pod Italijom: 1918-1943., Zagreb, 1944. [repr. Matica hrvatska, Rijeka, 1993.]; Vjekoslav BRATULIĆ, Pregled povijesti Istre, Otokar Keršovani, Rijeka, 1954.; Camillo De FRANCESCHI, Storia documentata della contea di Pisino, Società istriana di archeologia e storia patria, Venezia, 1964.; Božo MILANOVIĆ, Hrvatski narodni preporod u Istri, Istarsko književno društvo Sv. Ćirila i Metoda, Pazin, 1967.; Paola ROMANO, La questione giuliana, 1943-1947: la guerra e la diplomazia, le foibe e l'esodo, LINT, Trieste, 1997.

7 O hrvatskoj i talijanskoj gimnaziji vidi: D’ALESSIO, Il cuore conteso..., str. 140-153; Josip ŠIKLIĆ (ur.), Hrvatska gimnazija u Pazinu 1899.-1999., Međunarodni znanstveni skup, Gimnazija i strukovna škola Jurja Dobrile, Pazin, 1999.; Il Ginnasio Liceo Gian Rinaldo Carli di Pisino d'Istria. Atti del Convegno degli ex studenti per il centenario della fondazione, studi e memorie, La Famiglia Pisinota, Trieste, 2000. 
vili su dubok trag u povijesti i kulturnom razvoju Istrana te su se u idućim desetljećima odrazili i na njihove podjele.

Talijanski napad na Jugoslaviju 1941. godine imao je snažan politički i psihološki utjecaj, posebice na slovensko i hrvatsko stanovništvo improvizirane talijanske Ljubljanske provincije te proširene Riječke provincije i talijanske Dalmacije, kao i na izbjeglice te ostale stanovnike Jugoslavije u raspadu. Za stanovništvo je Istre posebno traumatičan bio preokret 1943. godine, počevši od savezničkoga, a kasnije i njemačkoga bombardiranja pa sve do kasnijeg »rata protiv civila«. Razdoblje od 1943. do 1945. godine bilo je puno tragičnih zbivanja, s tisućama mrtvih među svim jezičnim skupinama Poluotoka, sa stotinama spaljenih kuća u selima, mnogim masovnim grobnicama, uhićenima, mučenima i deportiranima u fašističke zatvore, u tršćanski logor Risiera di San Sabba, u njemačke koncentracijske logore te u jugoslavenske zatvoreničke logore na kraju rata. Nakon takvih ratnih događanja, ideološke, društvene i etničke podjele i tenzije već i ranije djelomice prisutne na najvećem jadranskom poluotoku, postale su nepovratne. Te su se tendencije iskazale još u okrilju političkih napetosti u doba Austro-Ugarske, njihov se intenzitet povećao nakon Prvoga svjetskog rata, zatim tijekom fašističkoga režima i, konačno, sudjelovanjem Italije u okupaciji i komadanju prve Jugoslavije i općenito ratnim zbivanjima.

Preuzimanje je vlasti od strane jugoslavenskih komunističkih partizana, u kolovozu 1943. godine, kao i kasnije u svibnju 1945. godine, bilo popraćeno brojnim krvoprolićima, u Italiji poznatima pod nazivom »fojbe«. Naziv potječe od kraških jama u koje su bacane brojne žrtve. ${ }^{8}$ Osuda ovih ubojstava i opisi »slavenske« represije protiv Talijana zauzimaju važno mjesto u Papovu opusu, od prvih djela (Criminali e Liberatori iz 1948., Foibe iz 1949. i Insegnamenti delle foibe istriane iz 1951. godine) pa sve do minucioznih opisa u publikacijama L'Istria e le sue foibe i L'Istria tradita iz 1999. godine. ${ }^{9}$ Prema Papovu mišljenju radi se o genocidu, a on je jedan je od najuvjerenijih zagovaratelja teze prema kojoj su žrtve odabrane samo zato »jer su bili Talijani«. ${ }^{10}$

8 O fojbama u Istri vidi: Giacomo SCOTTI, Krik iz fojbe, Adamić, Rijeka, 2008. Vidi i: Jože PIRJEVEC, Foibe - Una storia d'Italia, Giulio Einaudi Editore, Torino, 2009.; Raoul PUPO, Il lungo esodo. Istria: le persecuzioni, le foibe, l'esilio, Rizzoli, Milano, 2005.; Claudia CERNIGOI, Operazione Foibe - Tra storia e mito, Edizioni Kappa Vu, Udine, 2005.; Antonio FERRARA, »Beyond Ethnic Cleansing: Demographic Surgery in European History«, u: Maren BEHRENSEN - Lois LEE - Ahmet Selim TEKELIOGLU (ur.), Modernities Revisited, IWM Junior Visiting Fellows' Conferences, Vol. 29, Vienna, 2011. (dostupan u: http:/www.iwm.at/publications/5-junior-visiting-fellows-conferences/antonio-ferrara-2/\# edn1); Vanni D’ALESSIO, »Ponad Egzodusa i Fojbi. Nova talijanska literatura o Istočnoj granici«, Časopis za povijest Zapadne Hrvatske, VI-VII/6-7, Rijeka, 2011.-2012., str. 55-75; Franko DOTA, "Od usuda povijesti do fatalne greške: hrvatska historiografija o stradavanju i iseljavanju Talijana Istre $\mathrm{i}$ Rijeke«, Časopis za povijest Zapadne Hrvatske, VI-VII/6-7, Rijeka, 2011.-2012., str. 75-96.

9 Paolo De FRANCESCHI, Criminali e Liberatori, Centro di difesa Adriatica, Roma, 1948.; ISTI, Foibe, Centro di difesa Adriatica, Roma, 1949. [i Del Bianco, Udine, 1950.]; ISTI, Insegnamenti delle foibe istriane, Centro di difesa Adriatica, Roma, 1951.; Luigi PAPO de MONTONA, L'Istria e le sue foibe, Settimo sigillo, Roma, 1999.; ISTI, L'Istria tradita, Settimo sigillo, Roma, 1999.

10 »Procedimento giudiziario impropriamente noto come Processo delle foibe-Piškulić«, u: Mario DASSOVICH, 1945-1947 anni difficili e spesso drammatici per la definizione di un nuovo confine orientale italiano, Udine, 2005., str. 345. 
Motiv fojbi zauzima važno mjesto u čitavom povijesnom narativu Istre, napisanome posljednjih desetljeća iz pera talijanskih povjesničara, primjerice, Roberta Spazzalija i Raoula Pupe. ${ }^{11}$ Taj je motiv imao još značajniju ulogu u stvaranju identiteta ezulskih udruga. Sjećanja na fojbe bila su prenošena putem knjiga, pamfleta, časopisa koje su izdavale istarske udruge u Italiji i u svijetu tijekom Hladnoga rata. U tom razdoblju, kada je Papo u vlastitim knjigama i časopisima već podosta napisao o fojbama, u talijanskoj historiografiji one nisu spominjane. Ova se tendencija mijenja početkom devedesetih godina, pa teme poput istarskoga egzodusa doživljavaju porast povijesnoga legitimiteta i dobivaju na važnosti u talijanskoj javnosti. Pojavljuju se u povijesnim udžbenicima, kao i u maturalnim radnjama, te, naravno, u dnevnim novinama i ostalim sredstvima priopćavanja, na internetskim stranicama, posebice za (i oko) tzv. Dana sjećanja (Giorno del ricordo) koji je proglasila talijanska vlada 2004. godine. ${ }^{12}$

Iako bez pravoga legitimiteta talijanske historiografije, knjige su Luigija Pape desetljećima imale snažan utjecaj na stvaranje ezulskoga diskursa. Papo nije bio povjesničar po struci, kao ni Riječanin Mario Dassovich. Međutim, u Dassovichevim je djelima prisutna filološka oštroumnost za koju Papo nije pokazivao interes. ${ }^{13}$ Obojica su pripadali krugu ezula i obojica su otvoreno manifestirala protivljenje jugoslavenskom režimu te pripojenju Istre i Rijeke Jugoslaviji. Obojica bi bila zatvorena u jugoslavenskim zatvorima. Dassovich je kao mladić bio uhićen i osuđen za subverzivno djelovanje jer je dijelio letke, a Luigi Papo bio je uhićen na kraju rata, ali nije prepoznat. Tako je uspio izbjeći daleko gori tretman i najvjerojatnije osudu na smrtnu kaznu za počinjene ratne zločine. Obojicu također karakteriziraju patriotski duh i nacionalizam kojima su prožeta njihova djela. Usprkos svemu, antijugoslavenski usmjeren Dassovich nikad nije došao do toga da, poput Luigija Pape, preuveličava povijesne činjenice ili da u potpunosti izostavi i ne spomene važne povijesne fenomene samo zato jer nisu bili u skladu s njegovom ideološkom, povijesnom i nacionalnom vizijom povijesti Istre.

11 Roberto SPAZZALI, Foibe: un dibattito ancora aperto. Tesi politica e storiografica giuliana tra scontro e confronto, Lega Nazionale, Trieste, 1990.; Raoul PUPO - Roberto SPAZZALI, Foibe, Bruno Mondadori, Milano, 2003.; Raoul PUPO, Il lungo esodo. Istria: le persecuzioni, le foibe, l'esilio, Rizzoli, Milano, 2005.; ISTI, Trieste '45, Laterza, Roma - Bari, 2010. Vidi i: ISTI, »Foibe«, u: Enciclopedia Italiana, Enciclopedia Italiana - VII Appendice, Istituto dell’Enciclopedia Italiana, Rim, 2007.

O tome vidi: Mila ORLIĆ, »Javni diskursi, nacionalne memorije i historiografija na sjevernojadranskom prostoru«, Časopis za povijest Zapadne Hrvatske, VI-VII/6-7, Rijeka, 2011.-2012., str. 13-22; Vanni D'ALESSIO, »Rituality, Ideology and Emotions. Practices of Commemoration of the Giorno del Ricordo in Trieste«, u: Davor PAUKOVIĆ - Vjeran PAVLAKOVIĆ - Višeslav RAOS (ur.), Confronting the Past: European Experiences, Political Science Research Centre, Zagreb, 2012., str. 285-316; Mila ORLIĆ, "Se la memoria (non) mi inganna. L'Italia e il confine orientale: riflessioni sulla storia e sul suo uso pubblico«, Acta Histriae 23, Koper, 2015., str. 475-484; Federico TENCA MONTINI, »Politika sjećanja za postideološka vremena: slučaj Italije«, Politička misao: časopis za politologiju, 53(3), Zagreb, 2016., str. $7-25$.

13 Iz djela Marija DASSOVICHA izdvajam: La diaspora fiumana nella testimonianza di Enrico Burich, Del Bianco, Udine, 1986.; I molti problemi dell'Italia al confine orientale, Del Bianco, Udine, 1989.; Italiano in Istria e a Fiume: 1945-1977, Lint, Trieste, 1990.; Momenti di tensione a Trieste: dagli accordi di Osimo alla scomparsa di Tito, 1975-1980, Lint, Trieste, 1991.; La Fiumara e le sue due sponde: aspetti della questione adriatica, Del Bianco, Udine, 1997.; L'impero e il golfo: i territori degli Asburgo sull'Adriatico negli anni 1717-1814, Del Bianco, Udine, 2002. 
U dijelom autobiografskoj knjizi L’ultima bandiera. Storia del reggimento "Istria" iz 2000. godine Papo uspješno prikazuje atmosferu kontinuirana nasilja i sukoba u Istri između 1943. i 1945. godine. ${ }^{14}$ Međutim, na istim se stranicama jedva spominje okrutna represija koju su provodile nacističke snage kako bi preuzele kontrolu nad Istrom u listopadu 1943. godine i gotovo se opće ne govori o uhićenjima i deportacijama u Rižarnu, o likvidacijama na licu mjesta, o uništenju i paljenju kuća i čitavih sela, i općenito o zločinima koje su zajedno počinili Nijemci i Talijani sve do travnja 1945. godine, a u kojima je i sam Papo sudjelovao. U njegovu obimnu djelu Albo d'oro (La Venezia Giulia e la Dalmazia nell'ultimo conflitto mondiale) ${ }^{15}$ Talijani su prikazani, prije svega, kao žrtve Nijemaca, Amerikanaca, Slavena i partizana, bez spominjanja odgovornosti koje snose fašisti i talijanski vojnici.

Padom fašističkoga režima u srpnju 1943. i kapitulacijom Italije u rujnu iste godine, talijanski su vojnici, kao i civili, bili prisiljeni na donošenje važnih odluka i odabira. U većini su slučajeva odabiri dosljedno odražavali prijašnje orijentacije i uvjerenja, osim onih malobrojnih, učinjenih iz bezočnoga političkog oportunizma, ili su, pak, bili uvjetovani različitim društvenim i etničkim sredinama u kojima su se pojedinci kretali. Svi su, tko na ovoj, tko na onoj strani, bili uvučeni u sraz između redovnih i samoorganiziranih vojnih sila koje su se borile u Istri, u zatvoren krug nasilja i uzajamna optuživanja koji je snažno obilježio ovaj teritorij i lokalno stanovništvo, sprječavajući ponovnu uspostavu i normalizaciju društvenih odnosa na lokalnoj i široj razini.

Podjela Istrana prati etničke granice, ali ih i prelazi. Ideološka je razlika uzrokovala podjele koje su se uvukle među članove iste obitelji u kojima su se govorili i romanski i slavenski idiomi. Podjela je nastala, također, kao posljedica društvenih hijerarhija i različitih područja stanovanja i radnih mjesta. Radi se o kontekstu koji je postao zamršen zbog povijesne sposobnosti stanovništva slavenskoga podrijetla da integrira romanski idiom i kulturu, odnosno venetski i talijanski jezik. Širenjem teritorija talijanske države u razdoblju između dvaju svjetskih ratova većinski dio žitelja, čiji je materinski jezik bio hrvatski ili slovenski, govori i talijanski jezik, koristeći općenito istrovenetski dijalekt istom lakoćom kao i stanovništvo talijanskoga podrijetla ili identiteta. Budući da su stekli obrazovanje na talijanskom jeziku, Istrani rođeni u slavenskim obiteljima nisu nužno govorili književni talijanski (in lingua) jezik drugačije ili lošije od Istrana koji su bili romanskoga materinjeg jezika. Rasprostranjenost dvojezičnosti te široka pismenost na talijanskom jeziku među slavenskim stanovništvom (po podrijetlu ili obiteljskoj pripadnosti), u znaku ethnic surfinga između različitih jezičnih opcija koje su karakterizirale šarolik kulturni pejzaž Istre, već je i prije fašizma bila povezana s dinamikama društvene hijerarhije i različitosti te sličnim procesima u drugim srednjoeuropskim višejezičnim regijama. Radilo se o pokazatelju kulturnoga bogatstva Istrana, bez obzira na pripadnost, podrijetlo i nacionalnu identifikaciju.

Postojanje dvojezičnosti i pismenosti na talijanskom jeziku kod stanovništva koje je slavensko po obiteljskoj pripadnosti i podrijetlu, Papo interpretira, poput mnogih talijan-

14 Luigi PAPO de MONTONA, L’ultima bandiera. Storia del reggimento “Istria” del 2000, T.E.R., Roma, 2000

15 ISTI, Albo d'oro (La Venezia Giulia e la Dalmazia nell'ultimo conflitto mondiale), Unione degli Istriani, Trieste, [1989.] 1994. 
skih Istrana, kao dokaz »legende« o »pravima istarskih Slavena« koju treba oboriti te dokazati njenu lažnost. ${ }^{16}$ Usprkos svim povijesnim dokazima, Papo tvrdi da u razdoblju fašizma nije bilo nikakva »nametanja « talijanskih prezimena. ${ }^{17}$ Što se tiče $»$ ukidanja školske nastave i izdavaštva na slavenskom jeziku «, Papo je napisao: »Italija je osnovala škole, a ne ukinula, te je donijela kulturu tamo gdje je prije bila nepismenost i Slaveni druge narodnosti, koji su zaboravili zemlju podrijetla, ponosni su da su postali venetskim podanicima, da su postali talijanskim građanima usprkos stoljetnoj protutalijanskoj propagandi od strane Austrije - pohađali su talijanske škole ponosni na kulturu koja im je dana. $\aleph^{18}$ Odgovornost za međuetničke tenzije, prema njegovu mišljenju, snosi »pokoji slavenski propagandist koji je širio mržnju u selima« (qualche propagandista slavo che seminò odio nelle campagne). Kao dokaz u prilog tome, Papo navodi činjenicu da su mnogi dragovoljci koji su se s njim borili protiv partizana bili slavenskoga podrijetla, »potomci starih obitelji koje su naučile voljeti Italiju u sretnim vremenima venetske dominacije $\ll{ }^{19}$

U Papovim su djelima prisutne pojedine klasične teme koje karakteriziraju povijesnu interpretaciju talijanskoga jadranskog nacionalizma s početka dvadesetoga stoljeća. U svojim radovima govori o dolasku hrvatskoga i slovenskog stanovništva u Istru kao o "silasku Slavena« i inzistira na isključivo romanskom, venetskom i talijanskom karakteru Istre. Nadmetanje između talijanskih i hrvatsko-slovenskih stranaka tijekom razdoblja habsburške vladavine te između protalijanskih udruga Pro-Patria/Lega Nazionale i slovensko-hrvatske Ćiril i Metod, zajedno s politikom prisilnoga odnarođivanja koju je Italija provodila nakon Prvoga svjetskog rata i, na kraju, nasilje koje su provodili fašisti i nacisti tijekom Drugoga svjetskog rata, prema Papovu su viđenju umanjeni ili objašnjeni kroz prizmu obrane talijanstva.

Papo se nadovezuje na viziju čistoga etnonacionalnog suprotstavljanja političkih (i kulturnih) odnosa koja nakon Prvoga svjetskog rata, i nakon napuštanja umjerene politike istarskih i tršćanskih liberala, postaje dominantnom u diskursu talijanskih nacionalista sjevernoga Jadrana. Već nakon Prvoga svjetskog rata civilni upravitelj Venecije Julije, Antonio Mosconi, kao i kasnije ponovni osnivači Nacionalne lige (Lega Nazionale), u sporu oko Trsta nakon Drugoga svjetskog rata objedinjuju u slavenski komunizam bilo koju poziciju, pa čak i talijansku, koja se udaljavala od logike mi protiv njih. Nakon Prvoga svjetskog rata nazivani su slavokomunistima svi radnici i obrtnici koji su se usprotivili fašizmu postavljajući barikade u tršćanskoj četvrti San Giacomo. Za vrijeme i nakon Drugoga svjetskog rata partizani su za Papu bili pravi neprijatelji protiv kojih se trebalo boriti za obranu talijanske Istre. To ga je potaklo da se, nakon talijanske kapitulacije, nastavi boriti na strani njemačkoga borbenog aparata, koji je od jeseni 1943. preuzeo kontrolu nad sjevernim Jadranom i

16 PAPO, Montona..., str. 135.

17 Isto, str. 121.

18 U originalu: »L'Italia istituì scuole, non ne soppresse, portò la cultura là dove prima imperava l'analfabetismo e gli allogeni slavi - dimentichi ormai della terra d'origine, fieri di essere stati sudditi veneti, fieri di essere divenuti cittadini italiani nonostante più di un secolo di propaganda antitaliana svolta dall'Austria -, frequentavano le scuole italiane ed andarono fieri della cultura che loro veniva data «, isto, str. 121.

U originalu: »Discendenti da antiche famiglie che avevano appreso ad amare l'Italia al tempo della felice dominazione veneta«, isto, str. 146. 
dijelovima u zaleđu Alpa, preuzetim od novoformirane Talijanske Socijalne Republike, te osnovao područje Adriatische Küstenland, s otvorenim ambicijama priključivanja bivših područja Habsburške Monarhije Trećem Reichu. Kako navodi Corriere Istriano u studenom 1943., na Papovu je inicijativu osnovana fašistička organizacija u Motovunu, i to u trenutku potpunoga kraha fašističkoga režima u Italiji: »Fašistički odred Squadra d'Azione iz Motovuna, odsad Jurišna postrojba, osnovale su 3. listopada, na dan oslobođenja od banditske vladavine, hrabre udružene snage..${ }^{20}$ Skupina dragovoljaca koju Papo okuplja ulazi u sklop nove Dragovoljne policije za nacionalnu sigurnost (Milizia Volontaria per la Sicurezza Nazionale), kasnije u Republikansku narodnu gardu (Guardia Nazionale Repubblicana), koja će se na zahtjev Nijemaca spojiti u Policiju teritorijalne odbrane (MDT, Milizia difesa territoriale) i postati Landschutz Miliz. Papo je bio povjerenik nove fašističke organizacije Motovuna, na položaju vođe garnizona motovunske policije i gotovo je uvijek bio na čelu, kao poručnik, Treće jedinice druge regimente policije teritorijalne obrane »Istra« $\left(3^{\circ}\right.$ Compagnia del $2^{\circ}$ Reggimento "Istria" della MDT), da bi prema kraju rata stekao funkciju višega pobočnika prvoga bataljuna iste regimente (kojim je zapovijedao Libero Sauro, sin Nazarija Saura) te je bio jedan od vođa $P$ sektora (promidžbe) svoje regimente.

Saurovo smjenjivanje od strane Nijemaca, kao i druge epizode nerazumijevanja i napetosti s njemačkim civilnim vlastima (i u manjoj mjeri s vojnim vlastima), spominju se u više navrata u njegovim ratnim memoarima. U ovima Papo, kao da se nastoji opravdati što je podržao njemačke okupacijske snage, ponavlja: »Neprijatelj protiv kojeg se trebalo boriti bili su Slaveni. $\aleph^{21} »$ Slaveni koji su«, kako podsjeća Papo, naizgled zaboravljajući da su se iste stvari zbivale i na njegovoj strani, »bezobzirno ubijali sve koji nisu pristajali na njihove zahtjeve i priključili im se. (22 $^{22}$

Kako bi istaknuo mali broj pristaša i oskudnu podršku partizanskoj borbi za oslobođenje, u kojoj su također sudjelovali talijanski pojedinci i postrojbe, Papo navodi da »Slaveni nisu marili za potrebe stanovništva, već da su ih maksimalno izrabljivali«. ${ }^{23}$ Papo tako, primjerice, piše: »Ponekad su i sami seljaci dojavljivali mjesta na kojima su se skrivali slavenski vođe. ${ }^{24}$ Jugoslavenska se sjećanja bitno razlikuju, kao što je to slučaj sa stanovnicima Karojbe, koja je u to vrijeme bila selo Općine Motovun s gotovo u potpunosti hrvatskim stanovništvom. Ta sjećanja opisuju razdoblje koje počinje već u listopadu 1943. u kojem su fašistički odredi, takozvane squadre, kojima je zapovijedao sam Papo, provodili uhićenja i internirali u Njemačku osobe za koje su sumnjali da su partizani, gdje su kasnije neki od njih i okončali svoje živote. ${ }^{25}$

Jugoslavenska Državna komisija za utvrđivanje zločina okupatora i njihovih pomagača optužila je Papu za izdavanje zapovijedi o uhićenju oca i šesnaestogodišnjega sina te

\footnotetext{
20 Corriere Istriano, 21. 11. 1943.: »Come sorsero il Fascio e la Formazione d'assalto di Montona«.

21 PAPO, L'ultima bandiera..., str. 143.

22 Isto, str. 121.

23 Isto, str. 57.

24 Isto, str. 75.

25 Karojba i okolica, zbornik 1, Mjesna zajednica Karojba, Karojba, 1983., str. 142.
} 
je inzistirala na njegovoj odgovornosti za njihovo odvođenje u Njemačku (gdje su kasnije i umrli). Zbog izravna sudjelovanja te obavljanja funkcije zapovjednika lokalne jedinice motovunske policije, Papo je optužen za pljačku, palež i uništavanje imovine, za izdavanje zapovijedi za ubijanje, mučenje, odvođenje na prisilan rad drugih Istrana, a sve to u sklopu vojnih operacija te protiv nenaoružanih civila. Papo je prepoznat i optužen kao zapovjednik napada na sela i zaseoke središnje Istre u okolici Motovuna (između ostaloga napada na sela Radoslavi, Rapki, Špinovci, Močitad, Kuzmi). Jugoslavenska Komisija uključila je Papu na listu od 3798 talijanskih ratnih zločinaca dok se njegovo ime nije našlo na popisu od 768 osoba za koje je upućen zahtjev za izručenjem putem posebne komisije koju su osnovali Ujedinjeni narodi.

U trenutku demobilizacije, između 29. i 30. travnja 1945., Papo kreće prema Trstu gdje su ga partizani uhitili te je odveden u zatvor Coroneo da bi kasnije bio deportiran u zarobljenički logor u Prestranek u Sloveniji gdje nije bio prepoznat pa je, kako piše u djelu Prestrane. Diario di un condannato a morte, nakon mjesec dana zatvora oslobođen. ${ }^{26}$ Sakrivši se najprije u Trstu, doskora odlazi u Grado, zatim Milano te u Rim, posljednju postaju izbjeglištva. U Rimu u početku boravi i pod lažnim imenom zbog straha od mogućega izručenja Jugoslaviji (iako Italija nije ustupila Jugoslaviji niti jednoga osumnjičenog). U ovom je razdoblju on obilazio »Ured pograničnih krajeva« (Ufficio per le Zone di confine) pri uredu Predsjednika Vlade. Zaposlio se pri međunarodnom Crvenom križu gdje je radio u sklopu Udruge svjetske datoteke nestalih (Associazione Schedario Mondiale dei Dispersi), kako opisuje u djelu E fu l'esilio. Una saga istriana. ${ }^{27}$

Otad je Papo bio vrlo aktivan među udrugama ezula. Sudjeluje u osnivanju Nacionalnoga odbora (kasnije Udruge) Julijske krajine i Zadra i njihova časopisa »Jadranska obrana«. Trideset je godina vodio Centar za jadranske studije putem kojega je izdao neka od svojih povijesnih djela te eseje o kulturnoj tradiciji Istre. Dugo je godina obavljao dužnost zamjenika predsjednika Unione degli Istriani, jedne od najvećih ezulskih organizacija, sa sjedištem u Trstu. Bio je aktivan u krugu veteranskih udruga (poput Udruge grenadira Sardinije, unutar koje je i obnašao neke od funkcija) i ustrajno je pisao u časopisu Il Granatiere (»Grenadir«). ${ }^{28}$ Međutim, djelom L'Albo d'Oro. La Venezia Giulia e la Dalmazia nell'ultimo conflitto mondiale, ${ }^{29}$ Papo daje vjerojatno najvažniji i najkontroverzniji doprinos u stvaranju ezulskoga narativa o Drugom svjetskom ratu.

26 Luigi PAPO, Prestrane. Diario di un condannato a morte, L'Arena di Pola, Gorizia, 1984.

27 Luigi PAPO de MONTONA, E fu l'esilio. Una saga istriana, Edizioni Italo Svevo, Trieste, 1997.

28 Papo je bio aktivan kao industrijski rukovodilac, predsjednik Centra hotelijerskih studija (Centro Studi Alberghieri) u Chiancianu te kao savjetnik raznim poduzećima i društvima. Izdao je brojne eseje o brendiju i o gastronomiji, između ostaloga: Il brandy dall'a alla zeta, 1967.; Antologia del brandy italiano, 1972.; Profilo del brandy italiano, 1973.; A tavola con il brandy italiano (sa Divagazioni romane iz 1976., marchigiane iz 1978., liguri iz 1979. i napoletane iz 1982.); zajedno s Annom PESENTI napisao je: Il brandy (1978.), La Grappa (1984.), Il Marsala (1986.); bio je urednik raznih eseja srodnih tema te je napisao mnoga djela o korištenju, konzumiranju i opasnosti alkohola u Italiji i svijetu, u razdoblju između kraja šezdesetih i početka osamdesetih godina. 
L'Albo d'Oro, njegovo najobimnije djelo, predstavlja se kao statistički rad na svjedočanstvima kojima su prikupljeni podatci o palim osobama iz Julijske krajine i u Julijskoj krajini prije, u tijeku i nakon Drugoga svjetskog rata. Posveta $\gg$ Talijanima $\aleph^{30}$ na tragu je općega izgleda knjige čiji su podatci na prvi pogled nepristrani, ali u stvarnosti sadrže jednostrano viđenje. Na otprilike 800 stranica pojavljuju se imena poginulih svih nacionalnosti podijeljenih u razne kategorije, od vojnika do civila. Važno je spomenuti da su žrtve u logorima podijeljene na »ekshumirana tijela« (salme esumate), »potvrđene žrtve« (vittime accertate), ali i velikim brojem na neprovjerljive kategorije »pretpostavljenih žrtava« (vittime presunte). Usprkos svemu, u statističkom odjeljku na početku knjige, odmah nakon popisa stanovništva, iznijete su na vidjelo »fojbe i slavenska krvoprolića«, a zatim »koncentracijski logori«. Među ovima se spominju jugoslavenski logori u Ljubljani i Dubrovniku, ali ne i oni talijanski, poput Raba i Gonarsa, gdje su kraj života dočekale na tisuće Hrvata i Slovenaca, među kojima i mnogo djece. U tom se dijelu knjige ne spominje ni Risiera di San Sabba, koja se pojavljuje, na sasvim drugom mjestu, kao mjesto smrti u popisu imena

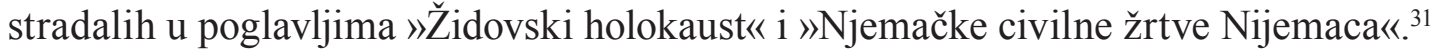

Ostala su poglavlja knjige posvećena civilima, koji su uglavnom podijeljeni (osim dvaju kratkih dijelova koja se odnose na žrtve s različitim uzrocima smrti) na: »Civilne žrtve Nijemaca: deportirani«, »Civilne žrtve bombardiranja« i dva su dijela posvećena »Civilnim žrtvama Slavena«. Nijemci i »Slaveni« pojavljuju se kao počinitelji, u skladu s jasnom strategijom etničke banalizacije koja izuzima bilo kakav tip ideološke ili nacionalne pripadnosti. Talijani se, naravno, spominju samo kao žrtve. U čitavoj knjizi prevladavaju podatci o vojnim žrtvama, koji su svrstani prema postrojbama i bojišnicama. Spominju se i partizani. Podatci o njihovim žrtvama nisu posebno izdvojeni, već su razasuti po cijeloj knjizi, a navodi ih se isključivo kao žrtve Nijemaca. Posebno mjesto zauzimaju podatci o postrojbama poput onih Mussolinijeve Talijanske Socijalne Republike (Repubblica Sociale Italiana, $R S I)$, X. divizije MAS te Republikanske nacionalne garde (GNR) i Policije teritorijalne obrane $(M D T)$.

Usprkos mnogim nepodudarnostima, knjiga je postala službenim tekstom koji je prihvatila Komisija ministarstva za dodjelu odlikovanja obiteljima žrtava fojbi, među kojima, dosad, prevladavaju obitelji članova talijanskih vojnih sila i policije aktivnih u Istri između 1943. i 1945. godine, a ne Istrani. S druge strane, dio knjige koji sadrži statističke podatke, koji bi trebali predstaviti određenu uravnoteženost, započinje čuvenim i često zloupotrijebljenim brojem od 350000 žrtava egzodusa, koji ne nalazi potvrdu u istraživanjima Hrvata Vladimira Žerjavića te Talijana Olinta Milete Mattiuza. Papo je bio jedan od prvih koji je počeo spominjati i propagirati ovaj broj, prema određenoj shemi koja izgleda kao da je unaprijed pripremljena i koja je imala odjeka u talijanskoj javnosti zbog svoje jednostavnosti i učinkovitosti, pojavljujući se na spomenicima i nadgrobnim pločama u raznim dijelovima Italije.

\footnotetext{
$30 \quad$ Isto, str. 199.

31 Isto, str. 23-27.
} 


\section{IZABRANA DJELA LUIGIJA PAPE (DE MONTONA):}

Kao Paolo De Franceschi: Criminali e liberatori, 1948.; Foibe, 1949. i 1950.; Insegnamenti delle foibe istriane, 1951. (sve Centro di difesa Adriatica u Rimu, Foibe također Del Bianco, Udine).

Kao Luigi Papo ili Luigi Papo de Montona: I beni italiani nella Venezia Giulia e Zara, Roma, 1953.; Nel 1943 le prime foibe in Istria, Roma, 1955.; Orsera d'Istria, Trieste, 1958.; Portole d'Istria, Trieste, 1958.; Patrioti istriani e dalmati, Trieste, 1960.; Una bandiera a Roma, Roma, 1968.; I caduti e i martiri della zona B dell'Istria, Roma, 1968.; Montona, Padova, 1974.; I caduti e i martiri della Dalmazia, Roma, 1979.; Tornare a casa, Roma, 1982.; Meminisse iuvavit, Roma, 1982.; Prestrane. Diario di un condannato a morte, Gorizia, 1984.; Contrordine. Compagnia volontari universitari del $3^{\circ}$ Granatieri di Sardegna, Bologna, 1988. (i 1990.); Albo d'oro. La Venezia Giulia e la Dalmazia nell'ultimo conflitto mondiale, Trieste, 1990. (i 1995.); Cinquant'anni dopo, 1943-1945, Lecce, 1995.; E fu l'esilio. Una saga istriana, Trieste, 1997.; Il reggimento "Istria", Lecce, 1997.; L'Istria e le sue foibe. Storia e tragedia senza la parola fine, vol. 1, Roma, 1999.; L'Istria tradita, Storia e tragedia senza la parola fine, vol. 2, Roma, 1999.; L'ultima bandiera. Storia del reggimento "Istria", Trieste, 2000.

\section{ARHIVSKI IZVORI:}

Archivio della Fondazione Ugo Spirito e Renzo de Felice, Roma: Fondo Luigi Papo (1933-1993); Archivio storico dell'Unione degli Istriani, Trieste: Fondo Luigi Papo (19601997); Arhiv Jugoslavije, Državna komisija za utvrđivanje zločina okupatora i njihovih pomagača, Broj fonda 110, fascikl 165 (broj 12593); Miodrag ZEČEVIĆ - Jovan P. POPOVIĆ, »Dokumenti iz Istorije Jugoslavije«, III tom: Državna komisija za utvrđivanje zločina okupatora i njihovih pomagača, Beograd, 1999.; Federal People's Republic of Yugoslavia, Report on italian crimes against Yugoslavia and its people. The State commission for the investigation of war crimes, Belgrade, 1946. 


\section{SAŽETAK}

\section{Luigi Papo (de Montona): Angažiran borac za talijansku Istru - od rata do pseudohistorije}

Luigi Papo bio je vođa motovunske fašističke skupine koja je sudjelovala u ratu s drugim dragovoljcima fašističkih milicija između 1943. i 1945. godine u Istri. Na kraju borbe uspio je, nakon kratka zatvora u Prestranku (Slovenija), pobjeći u Italiju kako bi izbjegao optužbe za ratne zločine koje je protiv njega pokrenula Jugoslavija. U sljedećim je godinama Papo nastavio svoj aktivizam, sada umjesto vojno djeluje politički, u udrugama istarskih ezula te u njihovim časopisima. Papo je bio plodan autor: napisao je brojne publikacije o staroj i novijoj povijesti Istre te o svojim iskustvima u ratu. Svojim stalnim aktivizmom sudjelovao je u izgradnji narativnoga diskursa o istarskom egzodusu i o fojbama te je imao snažan utjecaj u krugovima ezula i kasnije u različitim sektorima talijanske javnosti. Ovaj članak predstavlja neke trenutke Papova iskustva kao borca, aktivista i pisca, a posebice raspravlja o njegovu dihotomnom pogledu na jezične i nacionalne odnose u Istri.

\section{SUMMARY \\ Luigi Papo (de Montona): A Zealous Fighter for the Italian Istria - from the War to Pseudohistory}

Luigi Papo was the leader of the Motovun fascist group who participated in the War with other volunteers of fascist militias between 1943 and 1945 in Istria. At the end of the War, after a short imprisonment in Prestranek (Slovenia), he succeeded to escape to Italy to avoid the war crimes indictments launched against him by Yugoslavia. In the following years, now acting politically instead of militarily, Papo continued his activism in associations of Istrian exiles and in their journals. Papo was a prolific author: he wrote numerous publications about the early and modern history of Istria and about his experiences in the war. Through his constant activism, he participated in the development of the narrative discourse on the Istrian exodus and foibe and had a strong influence in the circles of exiles and later in the various sectors of the Italian public. This article presents some moments of Papo's experience as a fighter, activist and writer, and in particular discusses his dichotomous view of linguistic and national relations in Istria. 


\section{RIASSUNTO}

\section{Luigi Papo (de Montona): Combattente e attivista per l'Istria italiana - dalla guerra alla pseudo-storia}

Luigi Papo fu a capo della squadra d'azione fascista di Montona che prese parte alla guerra insieme agli altri volontari delle milizie fasciste tra il 1943 e il 1945 in Istria. Alla fine del combattimento riuscì, dopo un breve periodo trascorso nel carcere di Prestranek (Slovenia), a fuggire in Italia per evitare le accuse per crimini di guerra intraprese da parte della Jugoslavia. Negli anni successivi Papo continuò con il suo attivismo, non opera più in modo militare ma politico, attraverso associazioni degli esuli istriani e le loro riviste. Fu autore prolifico: scrisse numerose pubblicazioni sulla storia remota e recente dell'Istria e sulle proprie esperienze in guerra. Con il suo costante attivismo partecipò alla costruzione del discorso narrativo sull'esodo istriano e sulle foibe ed ebbe un forte influsso tra gli esuli e, successivamente, nei vari settori pubblici italiani. Questo articolo rappresenta alcuni momenti delle esperienze di Papo come combattente, attivista e scrittore, e discute in particolare della sua visione dicotomica relativa ai rapporti linguistici e nazionali in Istria. 